\title{
ACUTE PHASE RESPONSE AND OXIDATIVE STRESS PARAMETERS IN PNEUMONIC CAMEL CALVES (CAMELUS DROMEDARIUS)
}

\author{
W. M. EL-DEEB ${ }^{1,2}$ \\ ${ }^{1}$ Department of Clinical Studies, College of Veterinary Medicine and Animal Re- \\ sources, King Faisal University, Saudi Arabia; ${ }^{2}$ Department of Internal Medicine and \\ Infectious Diseases, Faculty of Veterinary Medicine, Mansoura University, Egypt
}

\section{Summary}

El-Deeb, W. M., 2015. Acute phase response and oxidative stress parameters in pneumonic camel calves (Camelus dromedarius). Bulg. J. Vet. Med., 18, No 3, 258-269.

\begin{abstract}
Pneumonia is an emerging problem in dromedary camels, while no data concerning the diagnostic importance of acute phase proteins and oxidative stress markers in pneumonic camel calves are available. Twenty five spontaneously pneumonic camel calves were used in this study. In addition, 25 healthy camel calves were used as control group. Blood samples were collected from both groups for determination of blood picture and analysis of lipoprotein profile, fibrinogen $(\mathrm{Fb})$, haptoglobin $(\mathrm{Hp})$, serum amyloid A (SAA), tumor necrosis factor-alpha (TNF- $\alpha$ ), interleukins (IL-6, IL-1 $\alpha$, IL1 $\beta$, IL10), interferon-gamma (IFN- $\gamma$ ) and malondialdehyde (MDA). Erythrocytic activity of superoxide dismutase (SOD), glutathione (GSH) and catalase (CAT) were determined in erythrocyte haemolysate obtained immediately after sampling from anticoagulated blood. The results revealed significant elevations in total leukocytic and neutrophil counts in pneumonic camel calves compared to control values. The concentrations of Hp, SAA, Fb, IL-6, IL- $1 \alpha$, IL1 $\beta$, IL-10, TNF- $\alpha$ and IFN- $\gamma$ were significantly higher $(1.6 \pm 0.1 \mathrm{~g} / \mathrm{L}, 26.4 \pm 3.23 \mathrm{mg} / \mathrm{L}, 5.1 \pm 1.30 \mathrm{~g} / \mathrm{L}, 19.7 \pm 1.6 \mathrm{pg} / \mathrm{mL}, 17.1 \pm 3.1 \mathrm{pg} / \mathrm{mL}$, $36.0 \pm 1.5 \mathrm{pg} / \mathrm{mL}, 14.3 \pm 0.5 \mathrm{pg} / \mathrm{mL}, 23.3 \pm 1.7 \mathrm{ng} / \mathrm{ml}, 29.5 \pm 2.2 \mathrm{pg} / \mathrm{mL}$ respectively) in pneumonic camel calves than in controls. The study showed a significant increase in MDA (21.36 $\pm 1.12 \mathrm{nmol} / \mathrm{g}$ protein) with significantly lower levels of erythrocytic GSH, SOD and CAT $(4.42 \pm 0.65 \mathrm{mmol} / \mathrm{g} \mathrm{Hb}, 3.1 \pm 0.22$ $\mathrm{U} / \mathrm{mg} \mathrm{Hb}$ and $10.4 \pm 1.3 \mathrm{U} / \mathrm{mg} \mathrm{Hb}$, respectively) in the pneumonic camel calves vs healthy controls. The present study concluded that lipid profile, APP, pro-inflammatory cytokines and oxidative stress indices could serve as diagnostic parameters for pneumonia in camel calves.
\end{abstract}

Key words: camel calves, haptoglobin, interleukins, oxidative stress, pneumonia, serum amyloid A

\section{INTRODUCTION}

Pulmonary diseases are among the emerging problems of camels that are causing considerable losses in production and death (Kane et al., 2005). 
The lung is a multifunctional organ, which has a role in the exchange of gases while at the same time the mucosal surface interacts with external oxidants. Oxidative stress is an active field of research in veterinary medicine implicated in numerous disease processes including sepsis, mastitis, enteritis, pneumonia, and respiratory \& joint diseases (Lykkesfeldt \& Svendsen, 2007)

Acute phase proteins (AAPs) are positive (up-regulated; $\mathrm{Hp}, \mathrm{Fb}$ and SAA) or negative (down-regulated; albumin, transferring and $\alpha$-fetoproteins) depending on the response to the challenge. This response is accompanied by alterations in lipid metabolism in the form of higher serum triglycerides and lower high-density lipoprotein levels (Cabana et al., 1989). Neutrophils in lungs respond to acute inflammation with a series of reactions ended by pathogen destruction (Soethout et al., 2002). These reactions involve phagocytising pathogens, increasing antibodies, complement fixation and finally stimulate the production of reactive oxygen and nitrogen species (Segal, 2005). Moreover, monocytes and macrophages produce pro-inflammatory cytokines (TNF- $\alpha$, IL1 $\beta$, IL-12 and IFN- $\gamma$ ), mediating the effect of APPs, favouring Thelper cell differentiation that construct a bridge between innate resistance and adaptive immunity (Trinchieri, 2003).

In spite of the emerging interest in using APPs as health indicators, limited studies exist with respect to their use in dromedary camels. Also, only few conditions in camel medicine have been investigated in regard to the effects of oxidative stress.

The aim of the present study was to investigate the alterations in lipoprotein profile, acute phase response, pro-inflammatory, anti-inflammatory cytokines and oxidative stress parameters in pneumonic camel calves.

\section{MATERIALS AND METHODS}

\section{Animals}

Twenty-five camel calves (2-6 months of age, 18 male and 7 female) were referred to the Veterinary Teaching Hospital, King Faisal University, presenting clinical signs of pneumonia including fever $(39.9 \pm 0.52$ $\left.{ }^{\circ} \mathrm{C}\right)$, dyspnea $(\mathrm{n}=25)$, mouth breathing, nasal discharge $(n=25)$, coughing $(n=25)$, depression $(\mathrm{n}=25)$, weight loss, increased respiratory rate $\left(21.4 \pm 3.2 \mathrm{~min}^{-1}\right)$ and crackles sound $(n=25)$ detected on lung auscultation. In addition, another 25 healthy camel calves (15 male and $10 \mathrm{fe}$ male) of similar age used as a control group. They were admitted to the Teaching Hospital for periodical check and were active and apparently strong. The selected control calves were free from any signs of respiratory disorders or other health problems. All calves were clinically examined.

\section{Sample collection}

Two separate blood samples were collected from pneumonic and healthy camel calves. One sample was taken in Eppendorf tube anticoagulated with EDTA for haematological studies. The second blood sample was taken in plain tubes, centrifuged at $3000 \mathrm{rpm}$ for $10 \mathrm{~min}$ and the clear serum was separated carefully and stored in Eppendorf tubes at $-20{ }^{\circ} \mathrm{C}$ until serum biochemistry analysis. Moreover, nasal swabs, bronchoalveolar lavage were collected from pneumonic camel calves, and subjected to bacteriological examinations. In addition, heart blood and lung samples were collected from necropsied calves (4/25) and subjected to bacteriological examinations. 
Acute phase response and oxidative stress parameters in pneumonic camel calves ...

\section{Cultural and biochemical identification of different pathogens}

The different samples were subjected to microbiological culture on defibrinated blood agar (5\%), MacConkey agar and Sabouraud agar, and incubated under aerobiosis at $37{ }^{\circ} \mathrm{C}$ for $72 \mathrm{~h}$. The same material was also incubated on blood agar (5\%) under anaerobic conditions at $37{ }^{\circ} \mathrm{C}$ for $120 \mathrm{~h}$. The isolated microorganisms identified using VITEK2 Compact, Biomérieux, France.

\section{Blood analysis}

Haematological profile. Haematological examination was carried out using automatic cell counter (VetScan HM5 Hematology system, ABAXIS).

Blood biochemistry parameters. The levels of total protein, albumin, triglycerides, cholesterol, high density lipoprotein cholesterol (HDL-C), low density lipoprotein cholesterol (LDL-C), aspartate aminotransferase (AST) and alanine aminotransferase (ALT) were determined in serum samples on a Beckman CX-7 autoanalyser using commercial kits (Sigma Chemical Co. Ltd., Poole, Dorset,UK).

Acute phase proteins, pro-inflammatory and anti-inflammatory cytokines. Serum Hp was determined using the haemoglobin-binding assay described by Makimura \& Suzuki (1982). SAA was measured by a solid-phase sandwich ELISA with a commercially available ELISA kit (Phase SAA kit, Tridelta Ltd., Ireland), according to the manufacturer's instructions. IFN- $\gamma$, IL-6, IL- $1 \alpha$, IL-1 $\beta$, IL-10 and TNF- $\alpha$, levels were determined from undiluted serum samples using commercially available ELISA Kits (Biosource, Diagnostic Corporation, USA). The plates were read at $450 \mathrm{~nm}$ on a computerised automated microplate ELISA reader (Bio TEC, ELX800G, USA).
Oxidative stress parameters. Glutathione (GSH) concentration in the RBC haemolysate was measured using the method of Beutler et al. (1963) based on the development of a stable yellow colour when 2-nitrobenzoic acid is added to sulfhydryl compounds. The amount of reduced product, thionitrobenzene, was measured at $412 \mathrm{~nm}$ and expressed as $\mathrm{mmol} / \mathrm{g} \mathrm{Hb}$. Superoxide dismutase (SOD) activity was estimated in the RBC haemolysate according to the method of Misra \& Fridovich (1972) based on the ability of SOD to inhibit the autoxidation of epinephrine to adrenochrome in an alkaline medium ( $\mathrm{pH}$ 10.2). The optical density was measured at $480 \mathrm{~nm}$ and expressed as $\mathrm{U} / \mathrm{mg} \mathrm{Hb}$. Catalase (CAT) activity was measured in RBC haemolysate by the method of Beers \& Sizer (1952). Decomposition of $\mathrm{H}_{2} \mathrm{O}_{2}$ was followed directly by decrease in absorbance at $240 \mathrm{~nm}$, and the difference in absorbance per $\mathrm{min} / \mathrm{mg} \mathrm{Hb}$ was taken as a measure of the CAT activity.

Lipid peroxidation in serum was estimated as thiobarbituric acid reactive substances (TBARS) according to Placer et al. (1966). The method is based on formation of a colour complex between lipid peroxidation products and thiobarbituric acid (TBA). Briefly, $0.2 \mathrm{~mL}$ of serum was added to $1.3 \mathrm{~mL}$ of $0.2 \mathrm{~mol} / \mathrm{L}$ Tris, 0.16 $\mathrm{mol} / \mathrm{L} \mathrm{KCl}$ buffer (pH 7.4). TBA (1.5 mL) was added and the mixture was heated in a boiling water bath for $10 \mathrm{~min}$. After cooling, $3 \mathrm{~mL}$ of pyridine-butanol $(3: 1, \mathrm{v} / \mathrm{v})$ and $1 \mathrm{~mL}$ of $1 \mathrm{~mol} / \mathrm{L} \mathrm{NaOH}$ were added. The absorbance was read at $548 \mathrm{~nm}$ against bi-distilled water as a blank. In this assay, 1,1,3,3-tetramethoxypropane was used as standard. Lipid peroxidation in serum was expressed as nmol serum malondialdehyde (sMDA)/g serum protein. 


\section{Statistical analysis}

All data presented as means \pm standard error of the means (SEM). The statistical significance between means was compared using Student's $t$-test; $\mathrm{P} \leq 0.05$ was considered significant. All tests were performed using the computer package of the statistical analysis system (SAS, institute, Inc, 2002).

\section{RESULTS}

The bacteriological examination of pneumonic camel calves showed that the isolated microorganisms were Staphylococcus spp. (13/25), Corynebacterium spp. (7/25), Streptococcus spp., (2/25) Pasteurella spp. (1/25), Klebsiella spp. $(1 / 25)$ and Pseudomonas (1/25). The mixed infection included Staphylococcus spp. \& Corynebacterium spp. (4/25), Staphylococcus spp. \& Streptococcus spp. (3/25), Pasteurella spp. \& Staphylococcus spp. (1/25) and Staphylococcus spp. \& Klebsiella spp. (1/25).
The haematological analysis of selected parameters demonstrated a significant elevation in total leukocyte and neutrophil counts in pneumonic camel calves compared to controls (Table 1).

The examined biochemical parameters were significantly $(\mathrm{P} \leq 0.05)$ increased in pneumonic camel calves except for total protein, albumin, albumin-globulin ratio, cholesterol and high density lipoprotein cholesterol (HDL-C) which were significantly $(\mathrm{P} \leq 0.05)$ lower compared to controls (Table 2).

Concerning the oxidative stress markers, the present study showed a significant $(\mathrm{P} \leq 0.05)$ increase in the levels of MDA with considerable $(\mathrm{P} \leq 0.05)$ decrease in the levels of erthrocytic GSH, SOD and CAT in the pneumonic camel calves vs healthy controls (Table 3 ). Serum concentrations of investigated APP and cytokines were significantly $(\mathrm{P} \leq 0.05)$ higher in pneumonic camel-calves (Tables 4 and 5).

There was a significant positive correlation between HP, SAA, fibrinogen,

Table 1. Haematological parameters in control $(n=25)$ and pneumonic camel-calves $(n=25)$. Data are presented as means \pm SEM

\begin{tabular}{lcc}
\hline Variables & Control camel calves & Pneumonic camel calves \\
\hline RBCs (T/L) & $10.64 \pm 0.50$ & $10.78 \pm 0.44$ \\
$\mathrm{Hb}(\mathrm{g} / \mathrm{L})$ & $156.70 \pm 15.20$ & $154.70 \pm 18.90$ \\
$\mathrm{PCV}(\mathrm{L} / \mathrm{L})$ & $0.29 \pm 0.01$ & $0.29 \pm 0.01$ \\
$\mathrm{MCV}(\mathrm{fL})$ & $24.52 \pm 1.32$ & $24.22 \pm 1.42$ \\
$\mathrm{MCHC}(\mathrm{g} / \mathrm{L})$ & $564.20 \pm 8.40$ & $558.2 \pm 9.40$ \\
WBCs (G/L) & $15.43 \pm 1.85$ & $22.40 \pm 1.40^{*}$ \\
Neutrophils (G/L) & $9.60 \pm 2.56$ & $18.60 \pm 3.40^{*}$ \\
Lymphocytes (G/L) & $5.75 \pm 2.50$ & $5.66 \pm 1.92$ \\
Monocytes (G/L) & $0.02 \pm 0.04$ & $0.02 \pm 0.03$ \\
Basophils (G/L) & $0.18 \pm 0.02$ & $0.20 \pm 0.03$ \\
Eosinophils (G/L) & $0.24 \pm 0.01$ & $0.25 \pm 0.01$ \\
\hline
\end{tabular}

$\mathrm{RBC}=$ red blood cell; $\mathrm{Hb}=$ haemoglobin; $\mathrm{PCV}=$ packed cell volume; $\mathrm{MCV}=$ mean corpuscular volume; $\mathrm{MCHC}=$ mean corpuscular haemoglobin concentration; $\mathrm{WBC}=$ white blood cell; * statistically significant difference between groups at $\mathrm{P} \leq 0.05$. 
Acute phase response and oxidative stress parameters in pneumonic camel calves ...

Table 2. Protein, lipid and enzyme profiles in control $(n=25)$ and pneumonic camel-calves $(n=25)$. Data are presented as means \pm SEM

\begin{tabular}{lcc}
\hline Variables & Control camel calves & Pneumonic camel calves \\
\hline Aspartate aminotransferase (U/L) & $47.32 \pm 1.22$ & $111.32 \pm 5.63^{*}$ \\
Alanine aminotransferase (U/L) & $16.56 \pm 1.83$ & $88.32 \pm 4.32^{*}$ \\
Alkaline phosphatase (U/L) & $38.63 \pm 1.56$ & $90.32 \pm 6.3^{*}$ \\
HDL-cholesterol (mmol/L) & $0.52 \pm 0.02$ & $0.24 \pm 0.01^{*}$ \\
LDL-cholesterol (mmol/L) & $0.15 \pm 0.01$ & $0.28 \pm 0.03^{*}$ \\
Cholesterol (mmol/L) & $0.86 \pm 0.12$ & $0.33 \pm 0.03^{*}$ \\
Triglycerides (mmol/L) & $0.47 \pm 0.13$ & $0.61 \pm 0.21^{*}$ \\
Total protein $(\mathrm{g} / \mathrm{L})$ & $64.30 \pm 5.30$ & $56.20 \pm 3.20^{*}$ \\
\hline
\end{tabular}

* statistically significant difference between groups at $\mathrm{P} \leq 0.05$.

Table 3. The levels of oxidative stress biomarkers and lipid peroxidation in control $(n=25)$, and pneumonic camel-calves $(n=25)$. Data are presented as means \pm SEM

\begin{tabular}{lcc}
\hline Variables & Control camel calves & Pneumonic camel calves \\
\hline Erythrocytic SOD (U/mg Hb) & $4.72 \pm 0.42$ & $3.10 \pm 0.22^{*}$ \\
Erythrocytic GSH (mmol/g Hb) & $7.15 \pm 0.33$ & $4.42 \pm 0.65^{*}$ \\
Erythrocytic catalase (U/mg Hb) & $15.70 \pm 0.40$ & $10.40 \pm 1.30^{*}$ \\
Serum MDA (nmol/g protein) & $12.36 \pm 0.85$ & $21.36 \pm 1.12^{*}$ \\
\hline
\end{tabular}

$\mathrm{SOD}=$ superoxide dismutase; $\mathrm{GSH}=$ reduced glutathione; $\mathrm{MDA}=$ malondialdehyde; * statistically significant difference between groups at $\mathrm{P} \leq 0.05$.

Table 4. Acute phase proteins (APPs) in control $(n=25)$ and pneumonic camel calves $(n=25)$. Data are presented as means \pm SEM

\begin{tabular}{lcc}
\hline Variables & Control camel calves & Pneumonic camel calves \\
\hline Positive APPs & & \\
Fibrinogen (g/L) & $3.3 \pm 0.30$ & $5.1 \pm 1.30^{*}$ \\
Serum amyloid A (mg/L) & $9.5 \pm 0.40$ & $26.4 \pm 3.23^{*}$ \\
Haptoglobin (g/L) & $0.3 \pm 0.03$ & $1.6 \pm 0.1^{*}$ \\
\hline Negative APPs & & \\
Albumin (g/L) & $34.5 \pm 1.3$ & $21.1 \pm 1.2^{*}$ \\
Globulins (g/L) & $22.3 \pm 2.3$ & $44.1 \pm 3.3^{*}$ \\
Albumin/globulin ratio & $1.62 \pm 0.22$ & $0.46 \pm 0.12^{*}$ \\
\hline
\end{tabular}

* statistically significant difference between groups at $\mathrm{P} \leq 0.05$.

leukocyte and neurtophil counts in camel calves under investigation as shown in Table 6 .

\section{DISCUSSION}

The present investigation is considered as one of the first in the field on camel calves' bronchopneumonia by using alte- 
Table 5. The examined pro-inflammatory and anti-inflammatory cytokines in healthy $(n=25)$, and pneumonic camel-calves $(\mathrm{n}=25)$. Data are presented as means \pm SEM

\begin{tabular}{lcc}
\hline Variables & Control camel calves & Pneumonic camel calves \\
\hline Pro-inflammatory cytokines & & \\
Interleukin-1 $\alpha(\mathrm{pg} / \mathrm{mL})$ & $9.3 \pm 0.3$ & $17.1 \pm 3.1^{*}$ \\
Interleukin-1 $\beta(\mathrm{pg} / \mathrm{mL})$ & $22.1 \pm 0.9$ & $36.0 \pm 1.5^{*}$ \\
Tumour necrosis factor- $\alpha(\mathrm{ng} / \mathrm{mL})$ & $15.3 \pm 0.5$ & $23.3 \pm 1.7^{*}$ \\
Interferon- $\gamma(\mathrm{pg} / \mathrm{mL})$ & $19.0 \pm 0.5$ & $29.5 \pm 2.2^{*}$ \\
\hline Anti-inflammatory cytokines & & \\
Interleukin-10 $(\mathrm{pg} / \mathrm{mL})$ & $10.2 \pm 0.4$ & $14.3 \pm 0.5^{*}$ \\
Interleukin-6 $(\mathrm{pg} / \mathrm{mL})$ & $13.9 \pm 0.5$ & $19.7 \pm 1.6^{*}$ \\
\hline
\end{tabular}

* statistically significant difference between groups at $\mathrm{P} \leq 0.05$.

Table 6. Pearson's correlation coefficients of selected variables in camel calves under investigation

\begin{tabular}{lcccc}
\hline Variables & Hp $(\mathrm{g} / \mathrm{L})$ & $\mathrm{SAA}(\mathrm{mg} / \mathrm{L})$ & $\mathrm{Fb}(\mathrm{g} / \mathrm{L})$ & WBCs $(\mathrm{G} / \mathrm{L})$ \\
\hline SAA $(\mathrm{mg} / \mathrm{L})$ & $0.670^{* * *}$ & & & \\
$\mathrm{Fb}(\mathrm{g} / \mathrm{L})$ & $0.688^{* * *}$ & $0.530^{* *}$ & & \\
WBCs $(\mathrm{G} / \mathrm{L})$ & $0.430^{*}$ & $0.406^{*}$ & $0.390^{*}$ & \\
Neutrophils (G/L) & $0.274^{*}$ & $0.318^{*}$ & $0.236^{*}$ & $0.796^{* * *}$ \\
\hline
\end{tabular}

$\mathrm{Hp}=$ haptoglobin, $\mathrm{SAA}=$ serum amyloid $\mathrm{A}, \mathrm{Fb}=$ fibrinogen; $\mathrm{WBCs}=$ white blood cells; *** very highly significant $(\mathrm{P}<0.0001)$, ** highly significant $(\mathrm{P}<0.001)$, * significant $(\mathrm{P}<0.05)$.

rations in lipid profile, APP, pro-inflammatory and anti-inflammatory cytokines and oxidative stress parameters. The significant $(\mathrm{P} \leq 0.05)$ elevation of total leukocyte and neutrophils counts in pneumonic camel calves (Table 1) may be attributed to a variety of immunomodulatory effects during lung inflammation (ElGhmati et al., 1996). Previous studies (Soethout et al., 2002; Civelek et al., 2007, Smith, 2009) reported such increase in leukocytes in pneumonic calves. Moreover, the pathological leukocyte range was observed in numerous infectious diseases (Civelek et al., 2007, El-Deeb, 2011). The significant $(\mathrm{P} \leq 0.05)$ increase in $\mathrm{ALT}$, AST and ALP activities and diminished liver albumin synthesis in pneumonic camel calves may be coupled with probable hepatocellular injury stimulated by inflammation (bronchopneumonia). Comparable elevated levels of ALT, AST and ALP were reported by Nikolic et al. (2006) in rats, Civelek et al. (2007) in neonatal calves and El-Deeb (2011) in buffalo calves.

The consequence of inflammation on hepatic albumin biosynthesis remains controversial (O'Leary et al., 2003). However, decreased albumin level observed in the current study agrees with previous findings reported by Civelek et al. (2007) in calves and and El-Deeb (2011) in buffalo calves. Marked reduction $(\mathrm{P} \leq 0.05)$ of total cholesterol and HDL-C levels, accompanied by significant elevation of VLDL-C and triglycerides of bronchopneumonic camel calves were similar to 
Acute phase response and oxidative stress parameters in pneumonic camel calves ...

findings in septic patients (Amersfoort et al., 2003), neonatal calves (Civelek et al., 2007) and buffalo calves (El-Deeb, 2011). The reduction in serum cholesterol in pneumonic camel calves may be attributed either to inflammatory processes and subsequent changes in lipoprotein metabolism or liver dysfunction (Civelek et al., 2007; El-Deeb, 2011). Lower HDL-C perhaps reflects its protective effects against inflammation, mediated via bacterial endotoxins binding and subsequent neutralisation (Wu et al., 2004). It was confirmed that inflammation leads to hypertriglyceridaemia in both humans and animals (Phetteplace et al., 2000). This may be due to an increased production of VLDL$\mathrm{C}$, diminished conversion of VLDL-C to LDL-C by the inhibition of lipoprotein lipase activity (Gouni et al., 1993) or stimulation of hepatic and adipose tissue lipolysis as well as hepatic fatty acid synthesis, which serve as substrates for hepatic VLDL synthesis (Feingold et al., 1992).

There are only few studies on the role of oxidative stress in bovine pneumonia. In cases of respiratory tract infections, the neutrophils are recruited to the lungs to contribute in elimination of invading pathogens by their phagocytic activity. In the present investigation there was a significant $(\mathrm{P} \leq 0.05)$ elevation in the levels of MDA with significant $(\mathrm{P} \leq 0.05)$ decrease in the levels of erythrocytic GSH, SOD and CAT in the pneumonic camel calves compared to their levels in healthy controls. The present results are in agreement with results obtained by Valko et al. (2007) in humans. They reported that oxidative stress may induce lipid peroxidation and severe tissue lesions which result in damaged cell organelles, nucleic acids, lipids and proteins. The present findings of oxidative stress are also in harmony with Art et al. (1999) and
Deaton et al. (2004) in horses with recurrent airway obstruction, Ledwozyw \& Stolarczyk (1992) in calves with bronchopneumonia, Al-Qudah (2009) in calves with acute pneumonia and in does with gangrenous mastitis (El-Deeb, 2013).

Decreased antioxidants (SOD, GSH and CAT), as found in the current study, may be attributed to the consumption of these enzymes in the protection of cells against oxidative injury by preventing initiation of the peroxidation process and production of final products such as TBARS, which are capable in inducing severe cellular damage (Halliwell, 1996). In certain cases of bovine pneumonia, the response to infection becomes extreme and yields many tissue-damaging products. Among the various products secreted by neutrophils are reactive nitrogen intermediates and $\mathrm{NO} \bullet$ which modulates both acute and chronic inflammatory reactions. $\mathrm{NO} \bullet$ is a mediator of capillary dysfunction and macromolecular leakage. $\mathrm{O}_{2} \bullet$ reacts with $\mathrm{NO} \bullet$ to produce $\mathrm{ONOO}^{-}$, causing tissue damage (Lykkesfeldt \& Svendsen, 2007). In bronchopneumonic calves, it was observed that isolated granulocytes produced ten times as much $\mathrm{O}_{2} \bullet$ and had lower plasma superoxide dismutase compared with healthy calves (Ledwozyw \& Stolarczyk, 1992). On the other hand, Wessely-Szponder et al. (2004) reported that isolated neutrophils released from infected animals produced greater amounts of $\mathrm{NO} \bullet$ and myeloperoxidase, which in combination may result in protein damage. The major antioxidant enzymes responsible for the degradation of reactive oxygen species are superoxide dismutase (which converts superoxide anion radicals to hydrogen peroxide), glutathione and catalase (which reduce hydrogen peroxides to alcohols and to water, respectively) (Halliwell, 1996; Silva et al., 
2012). Several studies have reported the decline of these enzymes in human patients with pneumonia (Cui et al., 1997). Ledwozyw et al. (1992) have reported a significant decrease of SOD activity in calves with bronchopneumonia correlated with high blood concentrations of superoxide radicals. Furthermore, distinct reduction of blood GSH concentrations was reported in human patients (Pacht et al., 1991).

Haptoglobin is $\alpha 2$-globulin synthesised in the liver (Feldman et al., 2000) and considered as the major APP in ruminants. Hp could be detected in infected animals before the onset of clinical signs and its concentration is used as an indicator of disease severity (Godson et al., 1996). The increased levels of $\mathrm{Hp}$ in cattle is interpreted as the outcome of tissue damage resulting from infection or inflammation (Eckersall et al., 1988). Similar results in cattle (Eckersall et al., 1988; Ganheim et al., 2003) reported the same significantly $(\mathrm{P} \leq 0.05)$ higher levels of $\mathrm{Hp}$ found in the current study (Table 4). On the contrary, other findings demonstrated either lower (Young et al., 1996) or unaltered (Wittum et al., 1996) Hp values of infected cows. The significant $(\mathrm{P} \leq 0.05)$ elevation of SAA of pneumonic camelcalves (Table 4) could be attributed to the physiological role of SAA in host defense during inflammation (Orro et al., 2011). Recently, similar marked elevation $(\mathrm{P} \leq 0.05)$ of SAA was reported in pneumonic calves (Nikunen et al., 2007; Orro et al., 2011) and pneumonic buffalo calves (El-Deeb, 2011; El-Bahr \& El-Deeb, 2013). Fibrinogen $(\mathrm{Fb})$ is a reliable indicator of inflammation and/or bacterial infection in cattle and sheep (Nikunen et al., 2007; Gonzalez et al., 2008; Orro et al., 2011). The substantial elevation of $\mathrm{Fb}$ shown in the present study may be attributed to the involvement of $\mathrm{Fb}$ in homeostasis, providing a substrate for fibrin formation and in tissue repair, providing a matrix for the migration of inflammatory related cells. Previous research demonstrated higher $\mathrm{Fb}$ levels in infected calves (Nikunen et al., 2007). Since blood samples were collected only once, the time course of APP, lipids and cytokines were not estimated. However, it well known that the concentrations of acute phase proteins as SAA increased more than 1000 times within 48-72 hours following inflammation in men and rabbits (Kushner, 1993). The mechanism for stimulation of APP production is via pro-inflammatory cytokines. The cytokine groups are the primary inducers of APP gene expression and each type initiates a different pattern of APP (Baumann \& Gauldie, 1994). Thus, the increase in different patterns of APP seen in the current study reflected the production of different amounts or types of cytokines (Table 4). It was reported that the resolution of pulmonary bacterial infections includes a superbly arranged balancing act of pro-inflammatory IL-1 and TNF- $\alpha$, IFN- $\gamma$ and anti-inflammatory cytokines IL-10 and IL-6 (Moore \& Standiford, 1998) as in the present study. Similar results for elevated levels of pro-inflammatory cytokines TNF- $\alpha$, IL1 $\beta$ and IFN- $\gamma$ in inflammation and infection were observed in pigs (Reeth \& Nauwynck, 2000), cattle (Gruys et al., 2005) and buffalo calves (El-Deeb, 2011; El-Bahr \& El-Deeb, 2013). In addition, expression of TNF and IL was significantly increased in the airways and lung lesions of infected calves (El-Deeb, 2011; El-Bahr \& ElDeeb, 2013). On the early stage of bacterial infection, resident alveolar macrophages become stimulated and discharge pro-inflammatory cytokines, resulting in 
Acute phase response and oxidative stress parameters in pneumonic camel calves ...

the eventual creation of a pro-inflammatory amplification loop between local or recruited macrophages or neutrophils and lymphocytes. As the infection is cleared, a second wave of anti-inflammatory cytokines is produced to localise the inflammatory response within the lung microenvironment and ultimately to downmodulate this immune response (Moore \& Standiford, 1998). So, the balance between pro-inflammatory and anti-inflammatory cytokines (which is disturbed in diseased calves) is a very important factor in the immnological response of calves to bacterial pneumonia.

\section{CONCLUSIONS}

The presented study shed a light on the pathophysiological role of lipid profile, oxidative stress markers, acute phase proteins and pro-inflammatory cytokines for bronchopneumonia in camel-calves. Future research efforts will be focused on the diagnostic and prognostic accuracy of such parametrs in camel calves.

\section{ACKNOWLEDGMENTS}

The financial support of Deanship of Scientific Research, King Faisal University is highly appreciated (Project No. 110031).

\section{REFERENCES}

Al-Qudah, K. M., 2009. Oxidative stress in calves with acute or chronic bronchopneumonia. Revue de Médecine Vétérinaire, 160, 231-236.

Amersfoort, E. S. V., T. J. C. Van Berkel \& J. Kuiper, 2003. Receptors, mediators and mechanisms involved in bacterial sepsis and septic shock. Clinical Microbiology Reviews, 7, 379-414.
Art, T., N. Kirschivink, N. Smith \& P. Lekeux, 1999. Indices of oxidative stress in blood and pulmonary epithelium lining fluid in horses suffering from recurrent airway obstruction. Equine Veterinary Journal, 31, 397-401.

Baumann, H \& J. Gauldie, 1994. The acute phase response. Immunology Today, 15, 74-80.

Beutler, E., O. Duron \& B. M. Kelly, 1963. Improved method for the determination of blood glutathione. Journal of Laboratory Clinical Medicine, 61, 882-888.

Beers Jr., R. F. \& I. W. Sizer, 1952. A spectrophotometric method for measuring the breakdown of hydrogen peroxide by catalase. Journal of Biological Chemistry, 195, 133-140.

Cabana, V. G., J. N. Siegel \& S. M. Sabesin, 1989. Effects of the acute phase response on the concentration and density distribution of plasma lipids and apolipoproteins. Journal of Lipid Research, 30, 39-49.

Civelek, T., K. Kav, I. Camkerten, A. H. Celik \& A. Acar, 2007. Effect of bacterial pneumonia in neonatal calves on serum lipids. Bulletin of the Veterinary Institute in Pulawy, 51, 503-507.

Cui, H., S. Yin, H. Gao \& G. Li, 1997. The comparison of selenium status between the children suffering from pneumonia and the normal children from kindergarten. Wei Sheng Yan Jiu, 26, 242-244.

Deaton, C. M., D. J.,Marlin, N. C., Smith, P. A., Harris, R. C., Schroter \& F. J. Kelly, 2004. Antioxidant supplementation in horses affected by recurrent airway obstruction. Journal of Nutrition, 134, 20652067.

Eckersall, P. D. \& J. G. Conner, 1988. Bovine and canine acute phase proteins. Veterinary Research Communications, 12, 169 178.

El-Bahr, S. \& W. EL-Deeb, 2013. Acute phase proteins, lipid profile and proinflammatory cytokines in healthy and bronchopneumonic water buffalo calves. American Journal 
of Biochemistry and Biotechnology, 2, 3440.

El-Deeb, W. M., 2011. Clinical and biochemical investigation of bacterial bronchopneumonia in Egyptian water buffalo calves: Acute phase proteins and lipoprotein profiles. Lucrări Științifice, $\mathbf{5 4}$ Medicină Veterinară (4), 412-417.

El-Deeb, W. M., 2013. Clinicobiochemical investigations of gangrenous mastitis in does: Immunological responses and oxidative stress Biomarkers. Journal of Zhejiang University SCIENCE B, 14, 33-39.

El-Ghmati, S. M., E. M. V. Hoeyveld, J. G. V. Strijp, J. L. Ceuppens \& E. A. Stevens, 1996. Identification of haptoglobin as an alternative ligand for CD11b/CD18. Journal of Immunology, 156, 2542-2552.

Feingold, K. R., I. Staprans, R. A. Memon, A. H. Moser \& J. K. Shigenaga, 1992. Endotoxin rapidly induces changes in lipid metabolism that produce hypertriglyceridemia: Low doses stimulate hepatic triglyceride production while high doses inhibit clearance. Journal of Lipid Research, 33, 1765-1776.

Feldman, B. F., J. G. Zinkl \& N. C. Jain, 2000. Schalm's Veterinary Hematology. $5^{\text {th }}$ edn, Blackwell, Ames, Iowa, pp. 1344.

Ganheim, C., C. Hulten, U. Carlsson, H. Kindahl, R. Niskanen \& K. P. Walter, 2003. The acute phase response in calves experimentally infected with bovine viral diarrhoea virus and/or Mannheimia haemolytica. Journal of Veterinary Medicine $B, \mathbf{5 0}, 183-190$.

Godson, D. L., M. Campos, S. K. Attah-Poku, M. J. Redmond, D. M. Cordeiro, M. S. Sethid, R. J. Harlanda \& L. A. Babiuka, 1996. Serum haptoglobin as an indicator of the acute phase response in bovine respiratory disease. Veterinary Immunology and Immunopathology, 51, 277-292.

Gonzalez, F. H., F. Tecles, S. MartınezSubiela, A. Tvarijonaviciute, L. Soler \& J. J. Cerón, 2008. Acute phase protein response in goats. Journal of Veterinary Diagnostic Investigation, 20, 580-584.
Gouni, I., K. Oka and J. Etienne, 1993. Endotoxin-induced hypertriglyceridemia is mediated by suppression of lipoprotein lipase at a post-transcriptional level. Journal of Lipid Research, 4, 139-146.

Gruys, E., M. J. M. Toussaint, T. A. Niewold \& S. J. Koopmans, 2005. Acute phase reaction and acute phase proteins. Journal of Zhejiang University SCIENCE B, 6 , 1045-1056.

Halliwell, B., 1996. Antioxidants in human health and disease. Annual Review of $\mathrm{Nu}$ trition, 16, 33-50.

Kane, Y., M. C. Kadja, R. Bada-Alambedji, O. E. Bezeid, J. A. Akakpo \& Y. Kaboret, 2005. Lung lesions and bacteria of the one-humped camel (Camelus dromedari$u s$ ) at Nouakchott slaughterhouse in Mauritania. Revue d'Élevage et de Médecine Vétérinaire des Pays Tropicaux, 58, 145-150.

Kushner, I., 1993. Regulation of the acute phase response by cytokines. Perspectives in Biology and Medicine, 36, 611-622.

Ledwozyw, A. \& H. Stolarczyk, 1992. The involvement of polymorphonuclear leucocytes in the pathogenesis of bronchopneumonia in calves. VI. Superoxide dismutase and lipoprotein lipase activities. Acta Veterinaria Hungarica, 40, 267-277.

Lykkesfeldt, J. \& O. Svendsen, 2007. Oxidants and antioxidants in disease: Oxidative stress in farm animals. The Veterinary Journal, 173, 502-511.

Makimura, S. \& N. Suzuki, 1982. Quantitative determination of bovine serum haptoglobin and its elevation in some inflammatory diseases. Japanese Journal of Veterinary Science, 44, 15-21.

Misra, H. P. \& I. Fridovich, 1972. The role of superoxide anion in the auto oxidation of epinephrine and a simple assay for superoxide dismutase. The Journal of Biological Chemestry, 247, 3170-3174.

Moore, T. A. \& T. J. Standiford, 1998. The role of cytokines in bacterial pneumonia: an inflammatory balancing act. Proceed- 
Acute phase response and oxidative stress parameters in pneumonic camel calves ...

ings of the Association of American Physicists, 110, 297-305.

Nikolic, J., I. Stojanovic, R. Pavlovic, D. Sokolovic \& G. Bjelakovic, 2006. The role of $\mathrm{L}$-arginine in toxic liver failure: Interrelation of arginase, polyamine catabolic enzymes and nitric oxide synthase. Amino Acids, 32, 127-131.

Nikunen, S., H. Hartel, T. Orro, E. Neuvonen, R. Tanskanen, S. L. Kivelä, S. Sankari, P. Aho, S, Pyörälä, H. Saloniemi \& T. Soveri, 2007. Association of bovine respiratory disease with clinical status and acute phase proteins in calves. Comparative Immunology, Microbiology \& Infectious Diseases, 30, 143-151.

O'Leary, M. J., M. Koll, C. N. Ferguson, J. H. Coakley \& C. J. Hinds, 2003. Liver albumin synthesis in sepsis in the rat: Influence of parenteral nutrition, glutamine and growth hormone. Clinical Science, $\mathbf{1 0 5}$ 691-698.

Orro, T., T. Pohjanvirta, U. Rikula, A. Huovilainen, S. Alasuutari, L. Sihvonend, S. Pelkonenc \& T. Soverib, 2011. Acute phase protein changes in calves during an outbreak of respiratory disease caused by bovine respiratory syncytial virus. Comparative Immunology, Microbiology \& Infectious Diseases, 34, 23-29.

Pacht, E., A. Timerman, M. Lykens \& A. Merola, 1991. Deficiency of alveolar fluid glutathione in patients with sepsis and adult respiratory distress syndrome. Chest, 100, 1397-1403.

Phetteplace, H. W., N. Sedkova, K. I. Hirano, N. O. Davidson \& S. P. Lanza-Jacoby, 2000. Escherichia coli sepsis increases hepatic apolipoprotein B secretion by inhibiting degradation. Lipids, 35, 10791086.

Placer, Z. A., L. L. Cushman \& B. C. Johnson, 1966. Estimation of product of lipid peroxidation (malonyldialdehyde) in biochemical systems. Analytical Biochemistry, 16, 359-364.
Reeth, K. V. \& H. Nauwynck, 2000. Proinflammatory cytokines and viral respiratory disease in pigs. Veterinary Research, 31, 187-213.

SAS, 2002. Statistical Analysis System, $1^{\text {st }}$ edn, User's Guide. SAS Institute Inc., Cary, NC, USA.

Segal, A. W., 2005. How neutrophils kill microbes. Annual Review of Immunology, 23, 197-223.

Silva, A. A., D. O. Ferreira, B. P. Santarosa, A. Dias, D. C. Damasceno \& R. C. Gonçalves, 2012. Effect of percutaneous transthoracic lung biopsy on oxidative metabolism in sheep. Journal of South African Veterinary Association, 83, 1-5.

Smith, B. P., 2009. Large Animal Internal Medicine, $4^{\text {th }}$ edn, Mosby Elsevier, United States.

Soethout, E. C., K. E. Muller \& V. P. M. G. Rutten, 2002. Neutrophil migration in the lung, general and bovine-specific aspects. Veterinary Immunology and Immunopathology, 87, 277-285.

Trinchieri, G., 2003. Interleukin-12 and the regulation of innate resistance and adaptive immunity. Nature Reviews Immunology, 3, 133-146.

Valko, M., D. Leibfritz, J. Moncol, M. T. Cronin, M. Mazur \& J. Telser, 2007. Free radicals and antioxidants in normal physiological functions and human disease. The International Journal of Biochemistry \& Cell Biology, 39, 44-84.

Wessely-Szponder, J., R. Bobowiec, F. Martelli, M. Wojcik \& U. Kosior-Korzecka, 2004. Assessment of neutrophil components as markers of lung injury in the course of bovine respiratory tract infections. Polish Journal of Veterinary Science, 7, 157-161.

Wittum, T. E., C. R. Young, L.H. Stanker, D. D. Griffin, L. J. Perino \& E. T. Littledike, 1996. Haptoglobin response to clinical respiratory tract disease in feedlot cattle. American Journal of Veterinary Research, 57, 646-649. 
Wu, A., C. J. Hinds \& C. Thiemermann, 2004. High-density lipoproteins in sepsis and septic shock: Metabolism, actions and therapeutic applications. Shock, 21, 210-221.

Young, C. R., T. E. Wittum, L. H. Stanker, L. J. Perino, D. D. Griffin \& E. T. Littledike, 1996. Serum haptoglobin concentrations in a population of feedlot cattle. American Journal of Veterinary Research, 57, 138 141.

Paper received 29.08.2014; accepted for publication 21.22.2014

\section{Correspondence:}

Dr. Wael Mohamed EL-Deeb Department of Clinical Studies, College of Veterinary Medicine and Animal Resources,

King Faisal University, AL-Ahsa, 31982

P.O. Box: 400. Saudi Arabia

Tel.: (00966) (050) 9296154,

Fax: (00966) (03) 5816635,

e-mail: drwaeleldeeb@yahoo.com 